\title{
T-Cell Surface Glycoprotein CD3 Eta Chain
}

National Cancer Institute

\section{Source}

National Cancer Institute. T-Cell Surface Glycoprotein CD3 Eta Chain. NCI Thesaurus. Code C38904.

T-cell surface glycoprotein CD3 eta chain is encoded by the human CD247 gene. This protein may be involved in both $\mathrm{T}$-cell activation and the innate immune response. 